\title{
Angiotensin-Converting Enzyme Inhibitors but Not Angiotensin II AT 1 Receptor Antagonists Affect Erythropoiesis in Patients with Anemia of End-Stage Renal Disease
}

\author{
Helmut Schiffl Susanne M. Lang \\ Nephrologisches Zentrum, Klinikum Innenstadt, Universität München, Deutschland
}

Dear Sir,

The origin of anemia of chronic renal failure is multifactorial. The primary defect of this anemia is decreased erythropoiesis, but a number of other factors may play a contributory role. Virtually all patients undergoing renal replacement therapy treated with recombinant human erythropoietin (rHU-EPO) achieve a significant rise in hemoglobin concentration or hematocrit (HCT). However, certain patients with anemia of end-stage renal disease require higher doses and need longer to reach stabilization. Numerous medical disorders or drugs may cause resistance to rHU-EPO therapy. Hematological changes associated with angiotensin-converting enzyme (ACE) inhibitors are well documented in healthy subjects, in patients with heart failure, and in patients with essential hypertension as well as chronic renal failure or renal transplants. Characteristically, these effects include a reduction in HCT levels which appears to be caused by a decrease in endogenous EPO production or activity. In anemic dialysis patients, therapy of hypertension or heart failure with ACE inhibitors may reduce the response to rHU-Epo therapy [1]. Angiotensin II receptor antagonists are often used to treat cardiovascular disorders associated with end-stage renal disease, but their effects on hematological parameters are largely unknown. This prospective randomized controlled study was carried out to compare the effects of these drugs on renal anemia and the requirement of EPO therapy.

Twenty-four anemic patients with endstage renal disease receiving regular hemodialysis were selected from four outpatient dialysis centers. They all gave informed consent to participate in the investigation. They all had normocytic-normochromic anemia, hypertension refractory to dialysis, and maintenance dialysis treatment for at least 6 months. The patients were matched according to demographic, biochemical, and treatment characteristics. The first patient of each pair was randomly assigned to one treatment group (captopril or losartan), the other patient of the pair received the alternative therapy. Deficiency of folic acid or vita$\min \mathrm{B}_{12}$, aluminum intoxication, severe hyperparathyroidism, hypothyroidism, active gastrointestinal bleeding, hematological diseases, malignancy, or chronic inflammation were excluded by appropriate methods in these patients. None of the patients had hypersplenism or a history of alcohol abuse, and they did not use immunosuppressive drugs affecting erythropoiesis. Captopril $(37.5-150 \mathrm{mg} /$ day $)$ or losartan $(25-50 \mathrm{mg} /$ day) were added to calcium antagonist based antihypertensive pharmacotherapy at doses to achieve adequate blood pressure control $(<140 / 90 \mathrm{~mm} \mathrm{Hg})$. All patients underwent conventional hemodialysis three times per week (4-5 h/session) using bicarbonate-buff- ered dialysate and biocompatible high-flux polysulfone or polyester-polymer membranes. Treatments were performed with volumetrically controlled ultrafiltration; the dry weight of the patients was assessed by measurements of the diameter of the inferior vena cava. The study protocol consisted of (1) a 3-month run-in period with introduction of the active drugs to the antihypertensive pharmacotherapy without rHU-EPO therapy; (2) a 3-month washout period without active drugs nor EPO replacement therapy, and (3) final 6-month period with concurrent therapy of renal hypertension by active drugs and treatment of renal anemia by rHu-EPO.

The initial EPO dose (epoietin alpha) was $50 \mathrm{U} / \mathrm{kg}$, thereafter doses were adjusted to maintain predialytic hemglobin concentrations of $10 \mathrm{~g} / \mathrm{dl}$. Intravenous iron was given to maintain serum ferritin above $400 \mu \mathrm{g} / \mathrm{l}$ and transferrin saturation above $25 \%$. HCT, endogenous EPO, ferritin, transferrin, and C-reactive protein were monitored monthly; intact parathyroid hormone and serum aluminum were measured quarterly. $\mathrm{K}_{\mathrm{t}} / \mathrm{V}_{\text {urea }}$ according to Daugirdas was calculated monthly.

There were no significant differences in age, gender, cause of end-stage renal disease, blood pressure control, main components of antihypertensive pharmacotherapy, parathyroid hormone or aluminum levels, and

\section{KARGER \\ Fax +4161306 1234 \\ E-Mail karger@karger.ch} www. karger.com (c) 1999 S. Karger AG, Basel

0028-2766/99/0811-0106\$17.50/0

Accessible online at: http://BioMedNet.com/karger

\author{
Prof. Helmut Schiffl \\ Nephrologisches Zentrum, Klinikum Innenstadt \\ Universität München, Ziemssenstrasse 1 \\ D-80336 Munich (Germany)
}

Tel. +49 8951602220 , Fax +49 8951604924 
$\mathrm{K}_{\mathrm{t}} / \mathrm{V}_{\text {urea }}$ values between the two treatment groups (table 1). There was also no significant difference in mean HCT, ferritin, or transferrin saturation at the start of study period A. Captopril but not losartan caused a statistically significant decrease in circulating endogenous EPO concentrations and corresponding HCT values. During the 3month run-in period, none of the patients had intercurrent diseases or signs of fluid overload; all patients had ferritin levels and transferrin saturation levels above minimum levels. To maintain a similar HCT during concomitant therapy of hypertension and anemia, the captopril group required a statistically significantly higher rHU-EPO dose (expressed as dose per patient and per session) than the losartan group (table 2).

This study in 24 matched patients with end-stage renal disease indicates that captopril aggravated anemia of chronic renal failure and decreased endogenous EPO production or activity. The ACE inhibitor also impaired the response to rHU-EPO therapy. A review of the literature showed no similar study assessing in detail the hematological effects of losartan. Our results confirm clinical observations in patients with essential hypertension showing no adverse effects of losartan on erythropoiesis [2]. The exact cause of the effects induced by ACE inhibitors on the erythropoietic activity is unknown, but it is clear that these drugs produce not only changes in erythropoietic regulatory factors, but alter control of erythropoiesis with reduced sensitivity to rHU-EPO. There is considerable evidence, including this study, that ACE inhibitors may reduce erythropoietic activity presumably by decreasing the angiotensin II concentration which in turn lowers EPO production and/or activity. Furthermore, recent data have demonstrated that factors other than EPO, such as insulin like growth factor 1 can promote erythropoiesis and correct anemia.
Morrone et al. [3] found that therapy with ACE inhibitors significantly reduced circulating insulin like growth factor 1 and HCT in patients with posttransplant erythrocytosis without modifying serum EPO levels. Thirdly, it has been shown that ACE inhibitors increased the plasma levels of the natural stem cell regulator N-acetyl-seryl-aspar-
Table 2. Effects of captopril or losartan on endogenous EPO concentrations and on response to rHU-EPO treatment (mean $\pm \mathrm{SD})$
Table 1. Demographic characteristics, biochemical data, and treatment parameters at recruitment (mean \pm SD where appropriate)

\begin{tabular}{lll}
\hline & $\begin{array}{l}\text { Captopril } \\
\text { group }\end{array}$ & $\begin{array}{l}\text { Losartan } \\
\text { group }\end{array}$ \\
\hline $\begin{array}{ll}\text { Number of patients } \\
\text { Age, years }\end{array}$ & 12 & 12 \\
Male/female ratio & $56 \pm 12$ & $58 \pm 13$ \\
Cause of renal failure & $7 / 5$ & $6 / 6$ \\
$\quad$ Chronic glomerulonephritis & 7 & \\
$\quad$ Chronic interstitial nephritis & 4 & 5 \\
$\quad$ Hypertensive nephropathy & 1 & 1 \\
Time on hemodialysis, months & $34 \pm 22$ & $36 \pm 27$ \\
Weight, kg & $65 \pm 15$ & $66 \pm 14$ \\
Blood pressure, mm Hg & & \\
$\quad$ Systolic & $142 \pm 12$ & $138 \pm 14$ \\
$\quad$ Diastolic & $84 \pm 8$ & $85 \pm 10$ \\
Antihypertensive drugs & & \\
$\quad$ Calcium antagonists & 8 & 7 \\
$\quad$ Beta blockers & 7 & 7 \\
Parathyroid hormone, pg/ml & $85 \pm 45$ & $98 \pm 35$ \\
Serum aluminum, $\mu \mathrm{g} / \mathrm{l}$ & $25 \pm 25$ & $20 \pm 10$ \\
$\mathrm{~K}_{\mathrm{t}} / \mathrm{V}_{\text {urea }}$ & $1.3 \pm 0.3$ & $1.4 \pm 0.3$ \\
\hline
\end{tabular}

\begin{tabular}{|c|c|c|c|c|}
\hline & \multicolumn{2}{|l|}{ Study A } & \multicolumn{2}{|l|}{ Study B } \\
\hline & $\begin{array}{l}\text { EPO } \\
\text { concentration } \\
\mathrm{pg} / \mathrm{ml}\end{array}$ & $\begin{array}{l}\text { HCT } \\
\%\end{array}$ & $\begin{array}{l}\text { EPO dose/ } \\
6 \text { months } \\
\text { U/session }\end{array}$ & $\begin{array}{l}\text { HCT } \\
\%\end{array}$ \\
\hline \multicolumn{5}{|l|}{ Captopril } \\
\hline Before treatment & $17.4 \pm 2.5$ & $27 \pm 1$ & - & $27 \pm 2$ \\
\hline After treatment & $11.3 \pm 1.5^{*}$ & $24 \pm 1^{*}$ & $2,413 \pm 157$ & $32 \pm 1 *$ \\
\hline \multicolumn{5}{|l|}{ Losartan } \\
\hline Before treatment & $18.4 \pm 2.5$ & $28 \pm 1$ & - & $28 \pm 2$ \\
\hline After treatment & $17.9 \pm 1.4$ & $29 \pm 1$ & $1,685 \pm 212^{*}$ & $33 \pm 2 *$ \\
\hline
\end{tabular}

$* \mathrm{p}<0.05$ compared to pretreatment value or to corresponding captopril treatment value.

Angiotensin II and Erythropoiesis 
tyl-lysyl-proline which prevents the recruitment of pluripotent hematopoietic stem cells [4].

The notion of a partial resistance to rHUEPO in end-stage renal disease patients treated with ACE inhibitors has clinical implications, because higher doses of EPO not only cause higher costs but may be associated with an increased incidence of side effects. Thus, ACE inhibitors should be reserved for hypertension or heart failure resistant to other medications in patients with end-stage renal disease.

\section{References}

1 Albitar S, Genin R, Fen-Chong M, Serveaux MO, Bourgeon B: High dose enalapril impairs the response to erythropoietin treatment in hemodialysis patients. Nephrol Dial Transplant 1998; 13:1206-1210.

2 Shand BI, Gilchrist NL, Nicholls MG, Bailey RR: Effect of losartan on haematology and haemorheology in elderly patients with essential hypertension: A pilot study. J Hum Hypertens 1995;9:233-235.
3 Morrone LF, Di Paolo S, Logoluso F, Schena A, Stallone G, Giorgino F, Schena FP: Interference of angiotensin-converting enzyme inhibitors on erythropoiesis in kidney transplant recipients: Role of growth factors and cytokines. Transplantation 1997;64:913-918.

4 Azizi M, Rousseau A, Ezan E, Guyene TT, Michelet S, Grognet JM, Lenfant M, Corvol P, Menard J: Acute angiotensin-converting enzyme inhibition increases the plasma level of the natural stem cell regulator $\mathrm{N}$-acetyl-serylaspartyl-lysyl-proline. J Clin Invest 1996;97: $839-844$ 